\title{
Bioactive natural compounds
}

\section{PROTEINS FROM GARLIC Allium sativum L. WHICH ARE ACTIVE AGAINST FUNGAL PATHOGENS OF BARLEY, WHEAT AND RICE, AND CAN STIMULATE SEEDS IN GARLIC}

\author{
O.G. KULIKOVA', D.I. MAL'TSEV', M.I. KARTASHOV'2, A.P. IL'INA', \\ V.P. YAMSKOVA ${ }^{3}$, I.A. YAMSKOV 1
}

\begin{abstract}
${ }^{1}$ A.N. Nesmeyanov Institute of Organoelement Compounds RAS, Federal Agency of Scientific Organizations, 28, ul. Vavilova, Moscow, 119991 Russia, e-mail koulikova_olga@mail.ru, mal-dima@yandex.ru, a.ilyina@gmail.com, yamskov@mail.ru; ${ }^{2}$ All-Russian Research Institute of Phytopathology, Federal Agency of Scientific Organizations, 5, Institute, pos. Bol'shie Vyazemy, Odintsovskii Region, Moscow Province, 143050 Russia, e-mail Kartashov.maxim@gmail.com;

${ }^{3}$ N.K. Kol'tsov Institute of Developmental Biology RAS, Federal Agency of Scientific Organizations, 26, ul. Vavilova, Moscow, 119334 Russia, e-mail yamskova-vp@yandex.ru

(ORCID: Kulikova O.G. orcid.org/0000-0002-2302-0034, Mal'tsev D.I. orcid.org/0000-0001-9478-9222, Kartashov M.I. orcid.org/0000-0001-6766-8409)

Received May 15, 2016
\end{abstract}

\section{Abstract}

Garlic (Allium sativum L., family Amaryllidaceae) plants are usually used because of bioactive compounds in their leaves and bulbs. Compounds extracted from this plant are often able to protect against some diseases. There is not enough information about infusions garlic extracts that can be used for plant pathogen control. Creating effective biologicals to protect plants against various diseases is an urgent task to improve crop yields. In this work, the bioactive compounds possessing activity against some phytopathogens were isolated from garlic plant bulbs Allium sativum L. A complex of lectin-allinase and peptide with molecular weight of 4392 Da was obtained from A. sativum bulbs. This complex described in literature before is consisted of allinase enzyme (molecular weight $54 \mathrm{kDa}$ ) and mannose-specific garlic lectin (ASA) with molecular weight of $6.4 \mathrm{kDa}$, and is formed when the bulb tissues are ground. Since, to our knowledge, no data on the biological action of this complex were reported before, we studied its activity against the pathogen of rice blast Magnaporthe grisea. This study showed that the lectin-allinaza complex had no suppressive effect on the pathogen spore germination (spore germination both in control and under treatment was at the 80-90\% level), but reduced the number of necrosis on treated leaves of rice (the percentage of uninfected leaves increased from $15 \%$ in control to $75 \%$ ). Thus, the complex did not affect M. grisea directly, but protected plants upon their infection by this pathogenic fungus. These findings suggest that lectinallinaza complex isolated from garlic bulbs is able to induce resistance to $M$. grisea, probably by activation of plant defense responses. The ability of obtained peptide not described in literature before to inhibit action of $B$. sorokiniana, the causative agent of Helminthosporium root rot and barley leaf blotch, at concentration corresponding to $10-11 \mathrm{mg}$ protein $/ \mathrm{ml}$, was shown on wheat and barley leaves. Since the peptide 4392 Da did not inhibit the growth of B. sorokiniana colonies in vitro, it can be assumed that the peptide is capable of activating the protective functions of the plant during the pathogen infection. When evaluating the effect of the peptide $4392 \mathrm{Da}$ on seed germination and growth stimulation in peas, cucumber, mustard, sunflower and garlic, the germination of garlic seeds increased by $13.6 \%(\mathrm{p}<0.01)$, while $65.5 \%(\mathrm{p}<0.01)$ increase in the length of its stems and a four-fold increase of the root length were observed, but the peptide had no effect on seeds and sprouts of the other crops tested. Thus, the resulting substances do not possess phytotoxicity, and due to its high activity at low concentrations show very low discharge at its application. Moreover, by virtue of its origin they are absolutely harmless for humans and animals and are environmentally safe technology of plant protection, which is especially important in modern agriculture.

Keywords: garlic, Allium sativum L., lectin, allinase, rice blast, rice, peptide, helmintospotium, growth stimulation

Leaves and bulbs of garlic Allium sativum L., family Amaryllidaceae, subfamily Allioideae) serve as a source of various biologically active substances for a long time [1-4]. Usually, however, studies of these parts are related to medicinal use [5-9], including issues of thrombocytosis [10] and carcinogenesis [11], while reports of use to counter phytopathogens are rare [12]. 
Among the means to protect plants from fungal diseases the majority are chemical. These are effective, but have a number of downsides, which include violation of biological balance, accumulation of residue chemicals in agricultural produce, progressing tolerance of pathogenic organisms, high cost of fungicides and catastrophic environmental pollution [13, 14]. Despite new chemical fungicides emerging on the market, the general situation with the protection of plants from disease and increasing productivity does not change in principle. The spread of such dangerous infections, as root rots, cucumber powdery mildew and cucumber false powdery mildew, cereal fusarium and rust, potato late blight, bacterial diseases of vegetable and fruit crops is epiphytotic and leads to a severe decrease in productivity and yield quality. Recently there is a growing interest in agricultural biologicals based on antagonist microorganisms, which increase resistance to stressors, and also to proteins and biologically active low molecular weight compounds. These biologicals are believed to better fit into integrated plant protection protocols, as they are effective, selective and relatively environment and human friendly $[15,16]$.

The range of preparations capable of inhibiting the development of diseases in plants, preserving or increasing productivity, is sufficiently broad nowadays. The majority of these, however, are synthetic compounds. They include derivatives of tetrahydrofuran and thiazolyl-5-carbonamide, a composition of 2-(5phenyl-3,6-diaza-2,7-dioxaocta-3,5-diphenyl)pheniacrylamide and anilinopyrimidine [17-19].

The enzyme allinase, found in garlic, catalyzes the formation of allicin, a biologically active compound which produces the characteristic garlic smell. Allinase, containing 5.5-6.0\% of residual neutral sugars, can bond with the mannose-specific garlic lectin (ASA - A. sativum allinase). However, only the method of forming and conditions of existence of this complex are studied as of today $[20,21]$. No data is available on its impact on living systems.

We were the first to show the biological activity (blast disease and spot blotch development suppression in cereals, stimulation of seed germination and seedling development in garlic) in the lectin-allinase complex of garlic, as well as in a new 4392 Da molecular weight peptide isolated by us from garlic bulbs.

The goal of the study was to isolate peptides from garlic and assess their antifungal and growth stimulating effect.

Techniques. Peeled bulbs (3 kg) of garlic (Allium sativum L.) Podmoskovnyi cultivar were milled into $1 \times 1 \mathrm{~cm}$ pieces, put into 101 of water-salt solution $\left(2.06 \times 10^{-2} \mathrm{M} \mathrm{NH}_{4} \mathrm{NO}_{3}, 1.88 \times 10^{-2} \mathrm{M} \mathrm{KNO}_{3}, 3.0 \times 10^{-3} \mathrm{M} \mathrm{CaCl}_{2}, 1.5 \times 10^{-3} \mathrm{M}\right.$ $\left.\mathrm{MgSO}_{4}, 1.25 \times 10^{-3} \mathrm{M} \mathrm{KH}_{2} \mathrm{PO}_{4}\right)$ and kept in a fridge for $4-5$ hours at $4{ }^{\circ} \mathrm{C}$. The resulting extract was centrifuged (3000 g, $30 \mathrm{~min})$, after which crystalline ammonium sulphate was added, with constantly stirring, to form a saturated salt solution $(780 \mathrm{~g} / 1)$ for protein precipitation [22]. The mixture was kept for 20 days at $4{ }^{\circ} \mathrm{C}$. After centrifuging for 30 minutes at $10000 \mathrm{~g}$ to remove salts the residue was dialyzed at $4{ }^{\circ} \mathrm{C}$ against $0.05 \mathrm{M}$ phosphate buffer $(1: 50 \mathrm{v} / \mathrm{v})$, the supernatant was dialyzed at against water.

Desalted protein residue was dissolved in the minimum amount of $0.05 \mathrm{M}$ phosphate buffer and fractioned by high performance gel permeation chromatography on a Bio-Sil TSK-125 $300 \times 7,5$ mm column (Bio-Rad Laboratories, USA), using a high pressure Agilent 1200 chromatography system (Agilent Technologies, USA). The mixture was eluted for $12 \mathrm{~min}$ at $0.5 \mathrm{ml} / \mathrm{min}$ with $0.05 \mathrm{M}$ phosphate buffer. The detection was performed at $\lambda=280 \mathrm{~nm}$. The first fraction to exit the column was collected, because it contains proteins with the highest molecular weight. The resulting fraction was analyzed by electrophoresis in $12.5 \%$ polyacrylamide gel with added SDS. The analysis resulted in two colored bands 
in the gel, corresponding to molecular weights of 6400 and 54000 Da. Tryptic protein hydrolysis was then performed for the bands, followed by MALDI-TOF mass-spectrometry (UltraFlex 2, Bruker Daltonic GmbH, Germany). The proteins obtained were identified by the SWISS PROT and NCBI databases. The concentration of the lectin-alinnase complex (LAC) was adjusted to $10^{-11} \mathrm{mg} / \mathrm{ml}$ with sequential ten-fold dilutions with water, which conforms with the mean value of the range of ultralow concentrations $\left(10^{-8}-10^{-15} \mathrm{mg} / \mathrm{ml}\right)$. The resulting preparation was used in the tests.

Desalted supernatant was concentrated at $36-40{ }^{\circ} \mathrm{C}$ and fractioned by reverse phase high-performance liquid chromatography (HPLC) in a hydrophobic Kromasil C18 column (Russia) $(4,6 \times 250 \mathrm{~mm})$ and a high pressure Agilent 1200 chromatography system. Elution was performed in the gradient of acetonitrile concentrations $(2-96 \%)$ in $0.1 \%$ water solution of trifluoroacetic acid ( $\mathrm{pH}$ 2.2) at $1 \mathrm{ml} / \mathrm{min}$ for $60 \mathrm{~min}$. The detection was performed at $\lambda=214 \mathrm{~nm}$. The resulting HPLC fraction was analyzed by mass spectrometry with an UltraFlex 2 TOF mass-spectrometer (Bruker Daltonic GmbH, Germany) using $\alpha$-cyano-4hydroxycinnamic acid as a matrix. From the HPLC fractions, among which the 4392 Da peptide (P 4392 Da) was the main component, we picked a fraction of $1 \mathrm{ml}$ with concentration peak $40 \mu \mathrm{g} / \mathrm{ml}$ (by peptide) for further work. The resulting peptide was adjusted to a concentration of $10^{-11}$ (by protein) with sequential ten-fold dilutions with water.

The rice blast agent Magnaporthe grisea (strain H5-3, race 007 with virulence genes $A v-k^{s+}, A v-a^{+}, A v-i^{+}$) and wheat and barley net blotch agent Bipolaris sorokiniana (strain Tul-12-1-3) were obtained from the State Collection of Phytopathogenic Microorganisms of the All-Russian Research Institute of Phytopathology. M. grisea was grown on agar carrot medium for $7-10$ days at $24{ }^{\circ} \mathrm{C}$, after which a washout of spores (conidia) was prepared in a laminar box $(40-50 \mathrm{ml}$ of sterile distilled water - SDW, 2-4 Petri dishes). The suspension was concentrated in a centrifuge $(10 \mathrm{~min}, 8000 \mathrm{rpm})$, its density was counted in a Goryaev's chamber and diluted to $10^{5} / \mathrm{ml}$ when necessary. B. sorokiniana was grown on potatoglucose agar (PGA) for 10-12 days at $24^{\circ} \mathrm{C}$. In a laminary box 10-15 ml SDW was added to the dishes with the agent, spores were brought down from aerial mycelium with a microbiological loop. The spore suspension was filtered through a sterile cotton filter and diluted with SDW to $10^{3}$ and $10^{5} \mathrm{spore} / \mathrm{ml}$ density.

The impact of LAC on rice blast development was assessed in pot test with susceptible rice (Oryza sative L.) cultivar Sha-tiao-tsao (contains complete resistance genes $P i-k^{s}$ ). The P 4392 Da activity in wheat and barley net blotch was assessed in a biotest with Lada cultivar wheat plants and Zazerskiy 85 cultivar barley plants. The growth stimulating effect of P 4392 Da was studied on cucumber (Fenix cultivar), pea (Sakharnyi cultivar), sunflower (Master cultivar) and garlic (Podmoskivnyi cultivar).

In the study of lectin-allynase complex (LAC) activity against $M$. grisea $45 \mu \mathrm{l}$ of SDW or LAC and $5 \mu \mathrm{l}$ of $10^{5}$ spores $/ \mathrm{ml}$ suspension was placed in wells of a Cellstar 96 well cell culture plate (Greiner Bio-One, Germany) for tissue cultures. The samples were incubated for 24 hours in the dark at $23{ }^{\circ} \mathrm{C}$. Germination rate (\%) was calculated in samples of 100 spores. The mean value for the test was determined. The significance of differences was evaluated by Student's $t$-test. The results were recorded using a Leitz Diavert inverted microscope (Leica Microsystems $\mathrm{GmbH}$, Germany).

In pot test of LAC impact on the development of rice blast 2-3-day-old seedlings were planted into plastic containers (0.5 1) with Sadovaya zemlya nonsterile universal nutrient soil and grown in a greenhouse for 21-24 days with 18 hours of daylight, at $22 / 30{ }^{\circ} \mathrm{C}$ (night/day) and good humidification. At leaf 3 
stage the plants were sprayed with LAC $\left(10^{-11} \mathrm{mg} / \mathrm{ml}\right.$ by protein) or distilled water (control) at $0.5 \mathrm{ml}$ per container and left in the same conditions. For each variant we used 3 containers, with 8 plants in each. Seven days after the spraying, when the leaf 4 appeared, its middle part (6 cm in length) was placed in an inoculation chamber. A suspension of $M$. grisea spores $\left(10^{5} / \mathrm{ml}\right.$, three $20 \mu \mathrm{l}$ drops) was put on the leaf with a drop holder [23]. The plants were kept for 2224 hours in the dark at $23{ }^{\circ} \mathrm{C}$ in a thermostat, then the drop holders and inoculation chambers were removed and the plants were put back in the greenhouse. Seven days after the inoculation the symptoms were assessed visually and the leaves were scanned with an Epson Perfection 3200 Photo tablet scanner (EPSON, Japan). The plant response was evaluated by the 5-point F.M. Laterell's scale [24]: lack of spots or weak necrosis -0 , brown spots -1 , brown spots $0.5-1 \mathrm{~mm}$ in diameter with rough edges -2 , rhomb-shaped spots $2-3 \mathrm{~mm}$ in diameter with brown center -3 , big rhomb-shaped grey-brown spots with sporulation in the center -4 , toxic effect spread over the whole plant -5 . The percentage $(\%)$ of inoculum drops, which formed compatible (4 points, susceptibility) and incompatible infection spots (1-3 points, resistance) or those, which had caused no symptoms ( 0 points, resistance) was calculated [25].

The impact of $\mathrm{P} 4392$ Da peptide on B. sorokiniana was studied by diffusion into agar [26]. Spore suspension $\left(10^{3} / \mathrm{ml}\right)$ aliquots of $100 \mu \mathrm{l}$ were spread onto potato-glucose agar (PGA) in Petri dishes. Three wells of $8 \mathrm{~mm}$ in diameter were made in agar, in which $100 \mu \mathrm{l}$ of peptide solution $\left(10^{-11} \mathrm{mg} / \mathrm{ml}\right)$, or $100 \mu \mathrm{l} \mathrm{SDW}$ in control, were put and incubated in a thermostat at $26^{\circ} \mathrm{C}$. At day 3 the diameter of growth delay areas was measured. The test was performed twice in three-fold repetitions. The development of net blotch infection after treatment with P 4392 Da peptide was assessed in a biotest using a modified method [26, 27]. Wheat and barley first fully unfolded leaves (segments of 5-6 cm in length, 8-10 pcs per Petri dish, 3 dishes for test and control each) were put on $1 \%$ agar with benzimidazole. For each leaf segment, one half was treated with $10 \mu \mathrm{l}$ of $B$. sorokiniana spore suspension in $\mathrm{P} 4392$ Da solution (protein concentration $10^{-11} \mathrm{mg} / \mathrm{ml}$, resulting spore suspension density $10^{5} / \mathrm{ml}$ ), and other half was treated with $10 \mu \mathrm{l}$ of water spores suspension of the same density (control). The results were assessed 7 days after the inoculation by the number of typical spots.

In the study of the impact of $\mathrm{P} 4392$ peptide $\left(10^{-11} \mathrm{mg} / \mathrm{ml}\right)$ on seed germination and seedling growth stimulation the sample for each culture consisted of four samples of 100 seeds (or 50 for big seeds). Sterilized filtering paper (2-3 layers soaked with peptide solution) in Petri dishes was a substrate. The seeds were organized in rows, with no less than $0.5-1.5 \mathrm{~cm}$ between them. The dishes were put into a thermostat and incubated at $25{ }^{\circ} \mathrm{C}$ for $7-10$ days. The percentage of germinated seeds was calculated, the length of roots and stems of seeding was measured.

The significance of differences was assessed by the Student's $t$-test (Statistica 6.0, StatSoft. Inc., USA).

Results. Extraction of lectin-allynase complex was performed at a low temperature $\left(4^{\circ} \mathrm{C}\right)$ which allowed to prevent non-specific proteolysis of proteins. The tryptic hydrolysis of the $6400 \mathrm{Da}$ and 54000 Da fractions, obtained after electrophoretic separation of the first chromatography peak using denaturing conditions, and the following spectrometry showed the 6400 Da protein to be homologous to the A-chain of the mannose specific agglutinin (lectin) of garlic, and the 54000 Da protein appeared to be the enzyme allynase. Therefore, we managed to isolate the lectin-allynase complex.

When studying whether or not this complex has a direct impact on a pathogen, we revealed that the viability of $M$. grisea spores did not differ in the control and LAC treatment groups (90-90\% of spores germinated). 

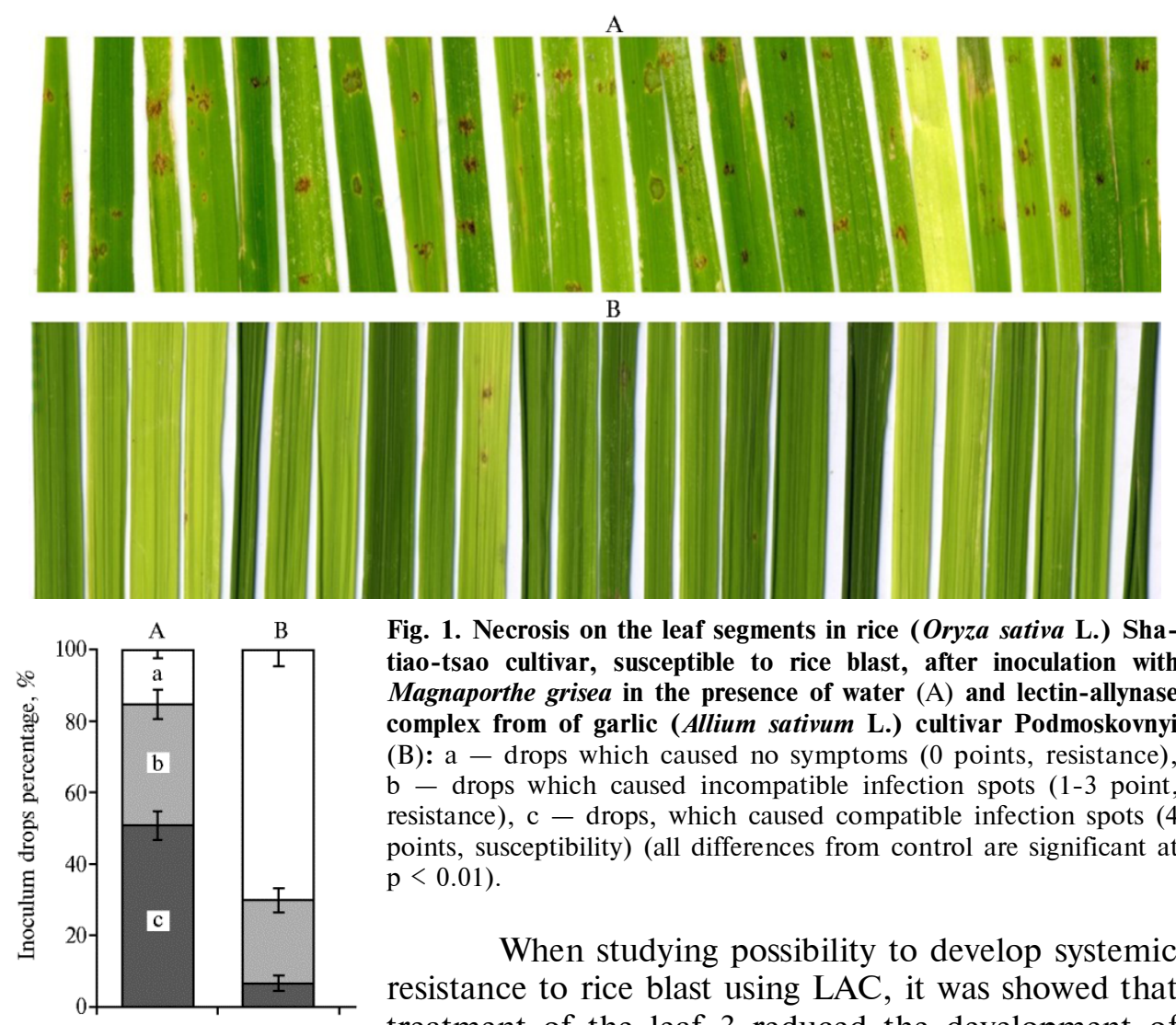

Fig. 1. Necrosis on the leaf segments in rice (Oryza sativa L.) Shatiao-tsao cultivar, susceptible to rice blast, after inoculation with Magnaporthe grisea in the presence of water (A) and lectin-allynase complex from of garlic (Allium sativum L.) cultivar Podmoskovnyi (B): a - drops which caused no symptoms ( 0 points, resistance), b - drops which caused incompatible infection spots (1-3 point, resistance), c - drops, which caused compatible infection spots (4 points, susceptibility) (all differences from control are significant at $\mathrm{p}<0.01)$.

When studying possibility to develop systemic resistance to rice blast using $\mathrm{LAC}$, it was showed that treatment of the leaf 3 reduced the development of the disease on the leaf 4 , which appeared later, that was manifested in a lesser number of necrosis compared to the control (Fig. 1).

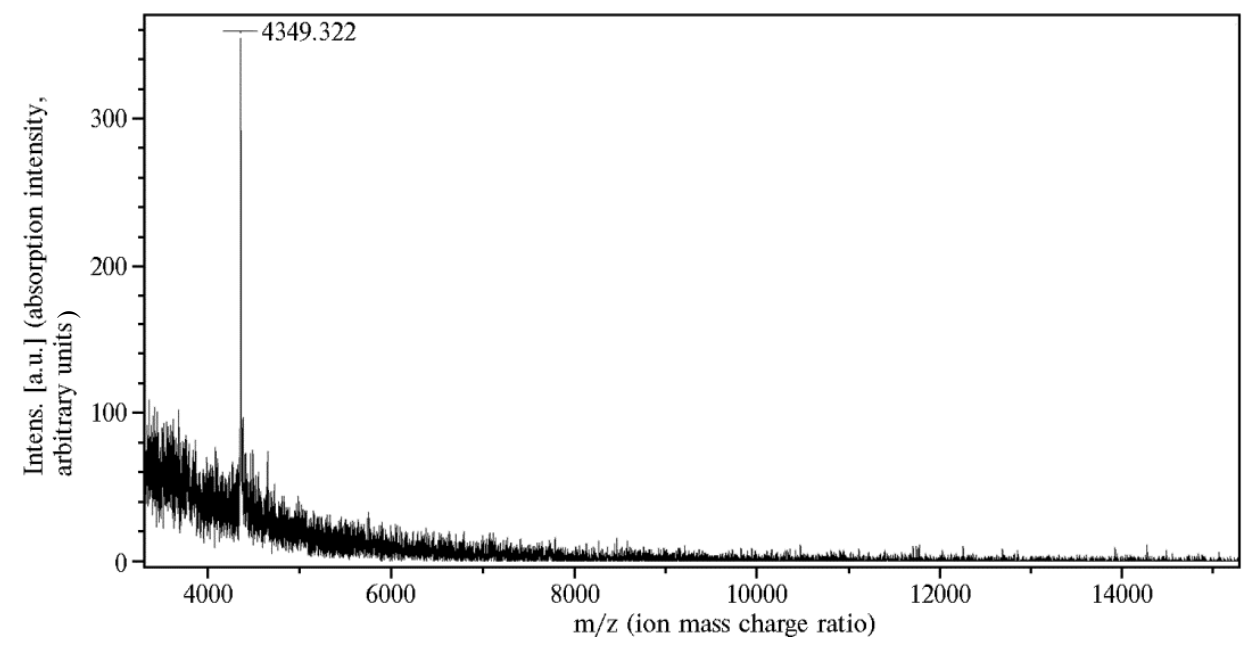

Fig. 2. The mass spectrum of the $\mathbf{P} 4392$ Da peptide isolated from garlic (Allium sativum $\mathbf{L}$.) cultivar Podmoskovnyi (Matrix-assisted laser desorption/ionization-Time of flight mass spectrometry MALDI-TOF, Time-of-flight mass-spectrometer UltraFlex2, Bruker Daltonic GmbH, Germany, matrix $-\alpha$-cyano-4-hydroxycinnamic acid).

At purification, large proteins are first to sediment from water-salt extract, while peptides remained in the solution [18]. Using reverse phase HPLC the main peptide of $4392 \mathrm{Da}$ (P $4392 \mathrm{Da}$ ) was isolated from the supernatant (Fig. 2). We did not find colony growth inhibition when studying the impact of 
this peptide at concentration of $10^{-11} \mathrm{mg} / \mathrm{ml}$ on B. sorokiniana. However, the biotest on wheat and barley leaves showed the P 4392 Da capability to completely suppress or significantly decrease manifestation of symptoms 7 days after the B. sorokiniana inoculation (Fig. 3).

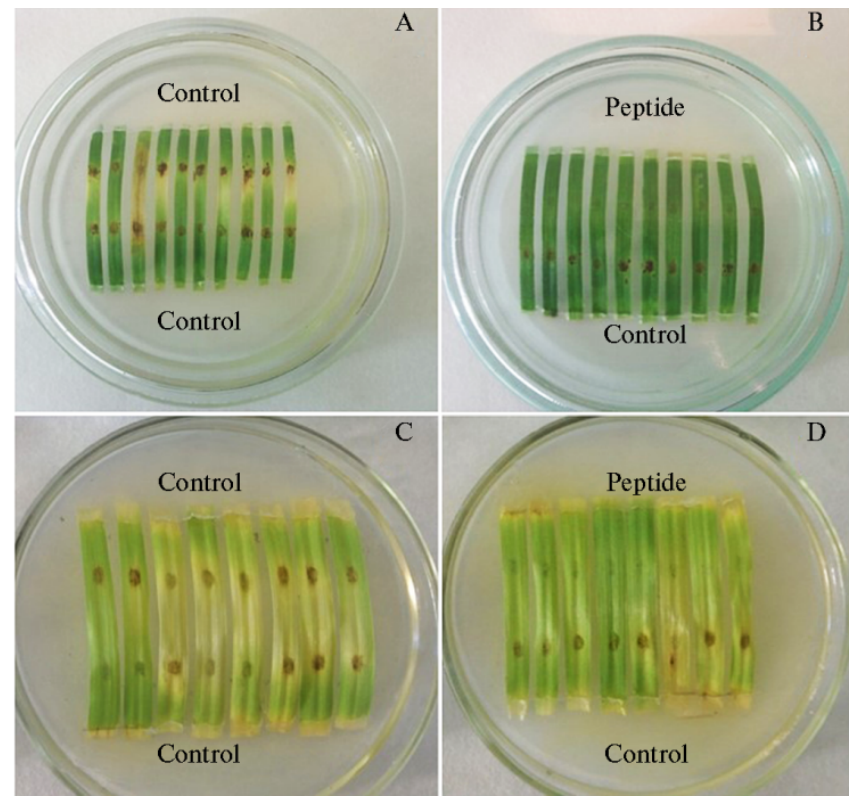

Fig. 3. The development of dark-brown net blotch on leaves of wheat cultivar Lada (upper row) and spring barley cultivar Zazerskiy 85 (lower row) in response to inoculation with Bipolaris sorokiniana in the presence of the $\mathbf{P} 4392$ Da peptide from garlic (Allium sativum L.) cultivar Podmoskovnyi: A, C - control (water spore suspension), B, D - joint application of spores and P 4392 Da (day 7 after inoculation).

P 4392 Da peptide had no phytotoxicity against wheat and barley, and also peas, cucumber, mustard, sunflower and garlic (data not shown). The peptide also had no effect on seed germination in pea, sunflower, mustard and cucumber, and further development of seedling of these crops in which an increase in stem and root length was not observed. At the same time, adding peptide in concentration of $10^{-11} \mathrm{mg} / \mathrm{ml}$ had a reliable positive effect on garlic seed germination (an increase by $13.6 \%, \mathrm{p}<0.05)$. It should be noted, that with the peptide the stem length in garlic seedlings increased by $65.5 \%$, and the root length was 4 times as much as that in the control (Fig. 4).

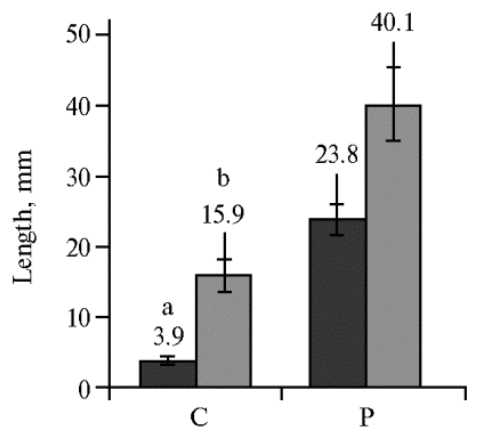

Fig. 4. Root (a) and stem (b) length in garlic (Allium sativum L.) cultivar Podmoskovnyi 10-days seedlings in the presence of P 4392 Da peptide isolated from garlic: $\mathrm{C}-$ control (water), $\mathrm{P}-$ peptide solution.

To date, various plant peptides with protective, antimicrobial and antifungal properties have been reported [28-31]. These are mostly cationic peptides, rich in cysteine, which have a broad range of effect against phytopatogens and pests. Most of the known antifungal peptides are effective in micromolar quantities. The P 4392 peptide that we have isolated from garlic differs from

other known peptides due to significantly lower effective concentration and the apparent capability of activating the plant's own defensive mechanisms at infection.

Therefore, bioactive substances of protein nature, effective against a range 
of phytopathogens, have been isolated from bulbs of garlic (Allium sativum L.). In our findings, the lectin-allynase complex (LAC), previously described by other researchers, has no direct effect against Magnaporthe grisea (the rice blast agent) in the concentration of $10^{-11} \mathrm{mg} / \mathrm{ml}$, but decreases the lesion of rice leaves infected with the pathogen. This can be considered as an evidence for LAC capability of inducing the plant's defensive response, leading to systemic resistance. In addition, we have isolated a 4392 Da peptide which effectively countered the development of net blotch infection (Bipolaris sorokiniana agent) in the $10^{-11} \mathrm{mg} / \mathrm{ml}$ concentration, and significantly stimulate seed germination and seedling growth in garlic.

\section{REFEREN C ES}

1. Van Damme E.J.M., A 11 e n A.K., P e u man s W.J. Related mannose-specific lectins from different species of the family Amaryllidaceae. Physiologia Plantarum, 1998, 73: 52-57 (doi: 10.1111/j.1399-3054.1988.tb09192.x).

2. Lanzotti V., Scala F., Bonanomi G. Compounds from Allium species with cytotoxic and antimicrobial activity. Phytochemistry Reviews, 2014, 13: 769-791 (doi: 10.1007/s11101-014-9366-0).

3. Kopec A., P latk owska E., Leszczynska T., S i k o ra E. Healthy properties of garlic. Current Nutrition \& Food Science, 2013, 9(1): 59-64 (doi: 10.2174/157340113804810888).

4. Van Damme E.J.M., Peumans W.J., Barre A., Rouge P. Plant lectins: a composite of several distinct families of structurally and evolutionary related proteins with diverse biological roles. Crit. Rev. Plant Sci., 1998, 17: 575-692 (doi: 10.1080/07352689891304276).

5. Borlinghaus J., Albrecht F., Gruhlke C.H., Nwachukwu I.D., S lus a renk o A.J. Allicin: Chemistry and biological properties. Molecules, 2014, 19: 12951-12618 (doi: 10.3390/molecules190812591).

6. Silagy C.A., Neil H.A. A meta-analysis of the effect of garlic on blood pressure. J. Hypertens., 1994, 12: 463-468 (doi: 10.1097/00004872-199404000-00017).

7. H a r r is J.C., C ot t re 11 S.L., P 1 u m m e r S., L 1 o y d D. Antimicrobial properties of Allium sativum (garlic). Appl. Microbiol. Biotechnol., 2001, 57: 282-286 (doi: 10.1007/s002530100722).

8. Li n X.Y., Li u J.Z., Milne r J.A. Dietary garlic suppresses DNA adducts caused by N-nitroso compounds. Carcinogenesis, 1994, 15: 349-352 (doi: 10.1093/carcin/15.2.349).

9. Warshafsky S., Kame r R.S., Sivak S.L. Effect of garlic on total serum cholesterol. A metaanalysis. Ann. Intern. Med., 1993, 119(7): 599-605 (doi: 10.7326/0003-4819-119-7_Part_1199310010-00009).

10. Kiesewetter H., Jung F., Pindur G., Jung E.M., Mrowietz C., Wenzel E. Effect of garlic on thrombocyte aggregation, microcirculation, and other risk factors. Int. J. Clin. Pharmacol. Ther. Toxicol., 1991, 29: 151-155.

11. Dorant E., Van den Brandt P.A., Goldbohm R.A., Hermus R.J., Sturmans F. Garlic and its significance for the prevention of cancer in humans: A critical view. Br. J. Cancer, 1993, 67: 424-429 (doi: 10.1038/bjc.1993.82).

12. Smirnova A.V. Puti povysheniya ekologicheskoi bezopasnosti pri vozdelyvanii kapusty $v$ Priamur'e. Avtoreferat kandidatskoi dissertatsii [Ways to improve environmental safety at cabbage cultivation in the Amur region. PhD Thesis]. Khabarovsk, 2011 (in Russ.).

13. Bondare n k N.V. Biologicheskaya zashchita rastenii [Bioprotection of plants]. Moscow, 1986 (in Russ.).

14. Velikanov L.L., Sidorova I.I. Ekologicheskie problemy zashchity rastenii ot boleznei. Itogi nauki $i$ tekhniki. Tom 6. [Ecological problems of plant protection against disease. Advances in science and technology. V. 6]. Moscow, 1988 (in Russ.).

15. Gren'e A., Pepen R. Proizvodnye tetragidrofurana, sposob ikh polucheniya $i$ sposob bor'by $s$ gribkami. RU 2079274. MPK6 A01N43/08, A01N43/50, A01N43/707, C07D307/18, C07D307/20, C07D405/06. Applicant Rhône-Poulenc Agrochimie (FR) [Tetrahydrofuran derivatives, their preparation and use against fungus. Appl. April 22, 1987. Publ. May 20, 1997] (in Russ.).

16. Egorov N.S. Osnovy ucheniya ob antibiotikakh [Theory of antibiotics - the fundamentals]. Moscow, 1986 (in Russ.).

17. Knauf-Baiter G., Tsurflyu R., Gzell B. Sposob bor'by s fitopatogennymi boleznyami kul'turnykh rastenii, fungitsidnaya kompozitsiya. $R U$ 2193847. MPK A01N37/50, A01N37/52, $A 01 N 43 / 40, A 01 N 43 / 54, A 01 N 43 / 653, A 01 N 43 / 828$ [A method to control phytopathogenic diseases of cultivated plants, a fungicide composition. Applicant Bayer AG (DE). Appl. April 22, 1997. Publ. August 27, 1998] (in Russ.).

18. Krasnov M.S., Yamskova V.P., Kulikova O.G., Il'ina A.P., Margasyuk D.V., Rybakova E.Yu., Yamskov I.A. Prikladnaya biokhimiya i mikrobiologiya, 2011, 47(2): 146-153 (in Russ.).

19. Kulikova O.G., Yamskova V.P., I l'ina A.P., M a rgasyu D.V., Molyavk a A.A., Y A m s k o v I.A. Prikladnaya biokhimiya i mikrobiologiya, 2011, 47(4): 1-5 (in Russ.).

20. Rabi nk ov A., Wi $1 \mathrm{chek}$ M., M i re $1 \mathrm{man}$ D. Alliinase (alliinlyase) from garlic (Alliium 
sativum) is glycosylated at ASN 146 and forms a complex with a garlic mannose-specific lectin. Glycoconjugate J., 1995, 12: 690-698 (doi: 10.1007/BF00731266).

21. S m e ets K., Van D a m me E.J., V a n Le uve n F., P e u m a n s W.J. Isolation and characterization of lectins and lectin-alliinase complexes from bulbs of garlic (Allium sativum) and ramsons (Allium ursinum). Glycoconjugate J., 1997, 14(3): 331-343 (doi: 10.1023/A:1018570628180).

22. Mirica A.K., Lockett M.R., S ny de r P.W., S hap i ro N.D., Mack E.T., Nam S., Whitesides G.M. Selective precipitation and purification of monovalent proteins using oligovalent ligands and ammonium sulfate. Bioconjugate Chem., 2012, 23(2): 293-299 (doi: $10.1021 / \mathrm{bc} 200390 \mathrm{q})$.

23. La p i k o v a V.P., Av e r'y a n ov A.A., P a s e chnik T.D. Mikologiya i fitopatologiya, 1995, 29(2): 44-47 (in Russ.).

24. Lat te re 11 F.M., M a r chetti M.A., G rove B.R. Co-ordination of effort to establish an international system for race identification in Pyricularia oryzae. In: The rice blast disease. The Johns Hopkins University Press, Baltimore, 1965.

25. We b ste r T.M. The southern states 10 most common and troublesome weeds in rice. Proceedings Southern Weed Science Society, 2000, 53: 247-274.

26. Pyzhikova G.V., Sanina A.A., Suprun L.M., Kurakhtanova T.I., Gogaeva T.I., Meparishvili S.U., Antsife rova L.V., Kuznetsov N.S., Ig nat ov A.N., $\mathrm{Kuz} \mathrm{z}^{\prime} \mathrm{m}$ i hev A.A. Metody otsenki ustoichivosti selektsionnogo materiala $i$ sortov pshenitsy $k$ septoriozu [Assessment of resistance to septoriosis in wheat breeding forms and varieties]. Moscow, 1989 (in Russ.).

27. S kla d n e v D.A. Metilotrofnye bakterii kak osnova biotekhnologicheskogo polucheniya stabil'no mechenykh biologicheski aktivnykh soedinenii. Doktorskaya dissertatsiya [Methylotrophic bacteria for biotechnological production of stable labeled bioactive compounds. DSci Thesis]. Moscow, 2000 (in Russ.).

28. Oparin P.B., Mineev K.S., Dunevsky Ya.E., Arseniev A.S., Belozersky M.A., Grish in E.V., Egorov T.A., V as s i levski A.A. Buckwheat trypsin inhibitor with helical hairpin structure belongs to a new family of plant defense peptides. Biochem. J., 2012, 446(1): 69-77 (doi: 10.1042/BJ20120548).

29. Slavokhotova A.A., Rogozhin E.A., Musolyamov A.K., Andreev Y.A., Oparin P.B., Berkut A.A., Vassilevski A.A., Egorov T.A., Grishin T.V., Odintsova T.I. Novel antifungal $\alpha$-hairpinin peptide from Stellaria media seeds: structure, biosynthesis, gene structure and evolution. Plant Mol. Biol., 2014, 84(1-2): 189-202 (doi: 10.1007/s11103-013-0127-z).

30. Egorov T.A., Odintsova T.I., Pukhalsky V.A., Grishin E.V. Diversity of wheat antimicrobial peptide. Peptides, 2005, 26: 2064-2073 (doi: 10.1016/j.peptides.2005.03.007).

31. Odintsova T.I., Egorov Ts.A., Musolyamov A.Kh., Odintsova M.S., Pukhalsky V.A., G ris h i n E.V. Seed defensins from T. kiharae and related species: genome localization of defensin-encoding genes. Biochimie, 2007, 89: 605-612 (doi: 10.1016/j.biochi.2006.09.009). 